\title{
Interspecific Hybridization in Cucumis-Progress, Problems, and Perspectives
}

\author{
Jin-Feng Chen ${ }^{\mathbf{1}}$ and Jeffrey Adelberg \\ Department of Horticulture, E-142 Poole Agriculture Center, Clemson University, Clemson, SC 29634
}

Interspecific hybridization is used to improve crops by transferring specific traits, such as pest and stress resistance, to crops from their wild relatives (Bowley and Taylor, 1987). When applicable, this approach is a very effective method of gene transfer. In nature, $\approx 30 \%$ to $35 \%$ of flowering plant species were created by interspecific hybridization, followed by chromosome doubling (Stebbins, 1971). Starting with interspecific hybridization, allopolyploids, such as allotetraploids, can be developed by doubling the chromosome number of the $F_{1}$ hybrid. Successful construction of an allopolyploid results in the creation of a new combination of genomes, or the production of a species that did not exist previously.

However, great effort may be required to hybridize cultivated and wild species. The first man-made interspecific hybrid was synthesized in 1717 between carnation (Dianthus caryophyllus L.) and sweet william (Dianthus barbatus L.) (Stalker, 1980). Since then, thousands of interspecific crosses have been attempted, but success has been rather limited. Chromosomal, genetic, cytoplasmic, or mechanical isolation barriers can handicap successful hybridization and utilization. It took plant breeders about 100 years to produce triticale - a new crop species created from the cross of wheat (Triticum aestivus L.) and rye (Secale cereale L.) (Zillinsky, 1985). Significant benefits and difficulties make interspecific hybridization an important objective for geneticists and plant breeders.

Interspecific hybrids in the Cucurbitaceae have been produced in several genera, including Cucumis (Deakin et al., 1971), Citrullus (Valvilov, 1925), Luffa (Singh, 1991), and Cucurbita (Weeden and Robinson, 1986). In

Received for publication 18 Mar. 1999. Accepted for publication 12 July 1999. Journal paper no. 4482 of South Carolina Agricultural Experiment Station, Clemson, S.C. The authors sincerely thank Dr. Yosuke Tashiro, Dr. Shiro Isshiki, and Dr. Sadami Miyazaki, Faculty of Agriculture, Saga Univ. of Japan, Saga, for the isozyme data presented in this paper, and Dr. Bill Rhodes and Dr. Vance Baird, Dept. of Horticulture of Clemson Univ., and Dr. Jack Staub, USDA/ARS, the Univ. of WisconsinMadison, for their review of this paper. This research was supported by the National Education Committee of the Peoples Republic of China, and by Research Grant Award No. US-2809-96R from the United States-Israel Binational Agricultural Research and Development Fund (BARD). The cost of publishing this paper was defrayed in part by the payment of page charges. Under postal regulations, this paper therefore must be hereby marked advertisement solely to indicate this fact.

${ }^{1}$ To whom reprint requests should be addressed. Current address: Nanjing Agricultural Univ., Nanjing 210095,P.R.China;e-mail:JFCHEN@nau.njau.edu.cn. the genus Cucumis, an amphidiploid was reported from the cross of $C$. anguria $\mathrm{L}$. and $C$. dipsaceus E. ex S. (Yadava et al., 1986). However, in the Cucurbitaceae only in Cucurbita has interspecific hybridization been successfully utilized for crop improvement (Robinson and Decker-Walters, 1997).

Cucumis contains two species of economic importance, melon (C. melo $\mathrm{L} ., 2 \mathrm{n}=24)$ and cucumber (C. sativus $\mathrm{L}$., $2 \mathrm{n}=14)$. The importance of wild Cucumis species has long been recognized because they possess resistance to pathogens, such as powdery mildew [caused by Sphaerotheca fuliginea (Schlechtend.: Fr) Pollacci], downy mildew [caused by Pseudoperonospora cubensis (Berk. \& M.A. Curtis) Rostovzev], anthracnose [caused by Colletotrichum orbiculare (Berk. \& Mont) Arx], and fusarium wilt (caused by Fusarium oxysporum Schlechtend.: Fr.) (Kirkbride, 1993; Leppick, 1966; Lower and Edwards, 1986). Genetic variation is relatively limited in cucumber (Staub et al., 1987); thus, efforts to create interspecific hybrids become more critical and meaningful. In 1859, Naudin first tried to cross melon with cucumber and other species (Naudin, 1859). Historically, various approaches (traditional and biotechnological) for interspecific hybridization have been used in Cucumis to overcome the fertilization barriers between cucumber, melon, and wild species, but with only limited success.
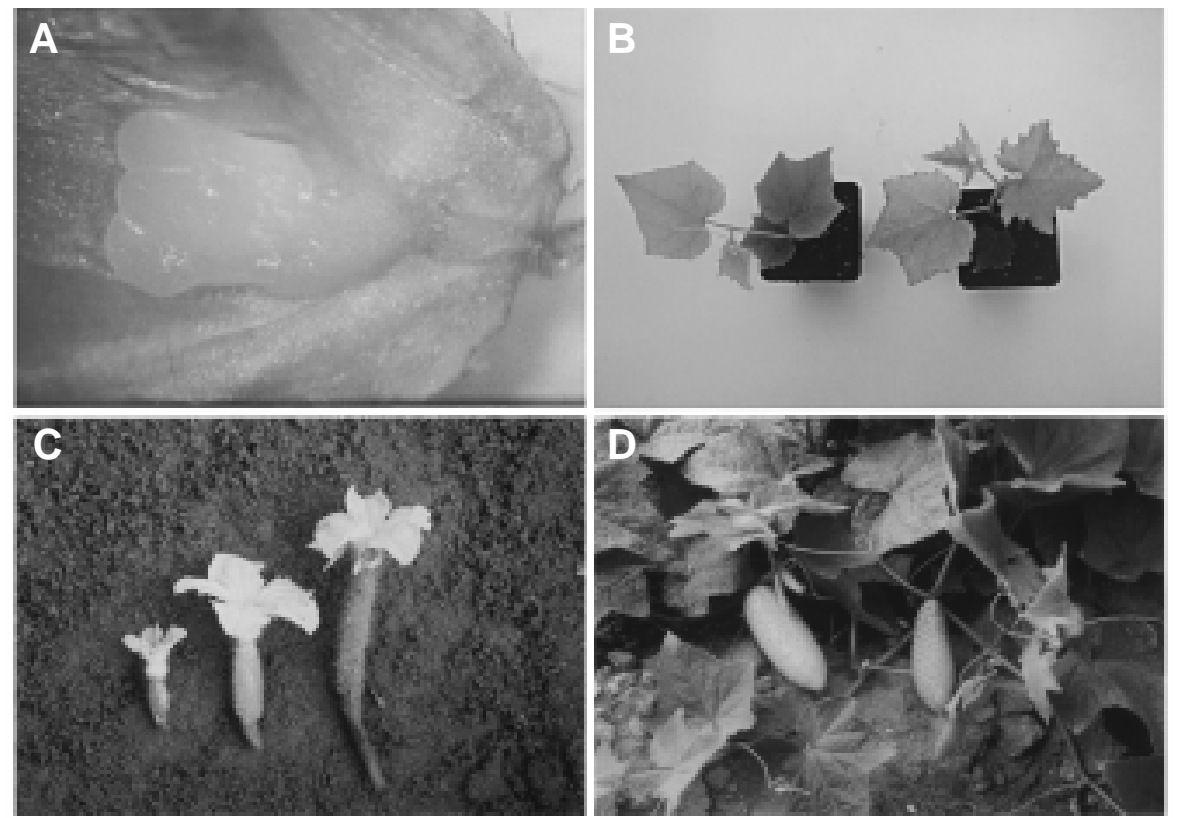

Fig. 1. (A) Embryo obtained from the interspecific hybrid between Cucumis sativus and C. hystrix. (B) The $\mathrm{F}_{1}$ diploid, sterile, hybrid plant form embryo rescue (left) and its chromosome-doubled tetraploid, fertile plant (right). (C) Female flowers of C. hystrix (left), C. sativus (right), and the $\mathrm{F}_{1}$ hybrid (middle).(D) Fruits set on the amphidiploid. 


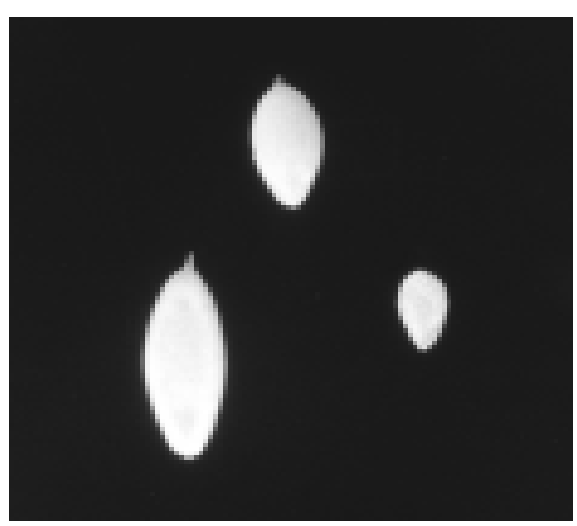

Fig. 2. Seeds harvested from the amphidiploid (below) and its diploid progenitors (Cucumis hystrix, upper left; $C$. sativus, upper right).

\section{PROGRESS: SYSTEMATIC STUDIES AND INTERSPECIFIC CROSSES IN CUCUMIS}

The genus Cucumis includes two distinct groups or subgenera, different in their origins and basic chromosome numbers (Jeffrey, 1980). Melon, and most other species in this genus with the basic chromosome number $\mathrm{n}=$ 12, are referred to as the African group. Cucumis sativus var. sativus and $C$. sativus var. hardwickii (Royle) Alefeld, with the basic chromosome number $\mathrm{n}=7$, are referred to as the Asian group. Under the current systematic system (Fig. 3), 30 species are grouped into six series in the subgenus melo (Kirkbride, 1993), instead of four groups (Jeffrey, 1980). Angurioide $i$ is the largest of the six series in the subgenus melo, and includes 19 species that are cross-compatible and can stimulate fruit set in members of the series melo. The species $C$. sativus and $C$. hystrix are included in the subgenus Cucumis (Kirkbride, 1993).

Successful utilization of wild species to improve a crop species largely depends on species relationships. To understand the phylogenetic affinities among species, studies on comparative morphology, crossability, chromosome pairing, isozyme variability, and DNA variation in Cucumis have been carried out (Table 1). Although the number of groups varied with each study, the basic phylogenetic trees developed from the different experiments were similar. For instance, most of the African Cucumis species form a close group (Anguria), which is distant from both melon (C. melo), and the other isolated species, such as $C$. metuliferus E. Meyer ex Naudin, C. sagittatus $\mathrm{P}$., and $C$. humifructus Stent, which are all far from each other. Cucumber (C. sativus) is the most distant species within the genus (PerlTreves and Galun, 1985; Perl-Treves et al., 1985).

In 1989, Cucumis hystris Chakr., a wild Cucumis species, was rediscovered and identified by Jinfeng Chen et al. in Yunnan Province of China (Chen et al., 1994). This unique species may improve our understanding of phylogenetics in Cucumis. Cucumis hystrix is the only $2 \mathrm{n}=24$ Cucumis species native to Asia (Figs. 4 and 5). This finding challenges the basic chromosome number theory that

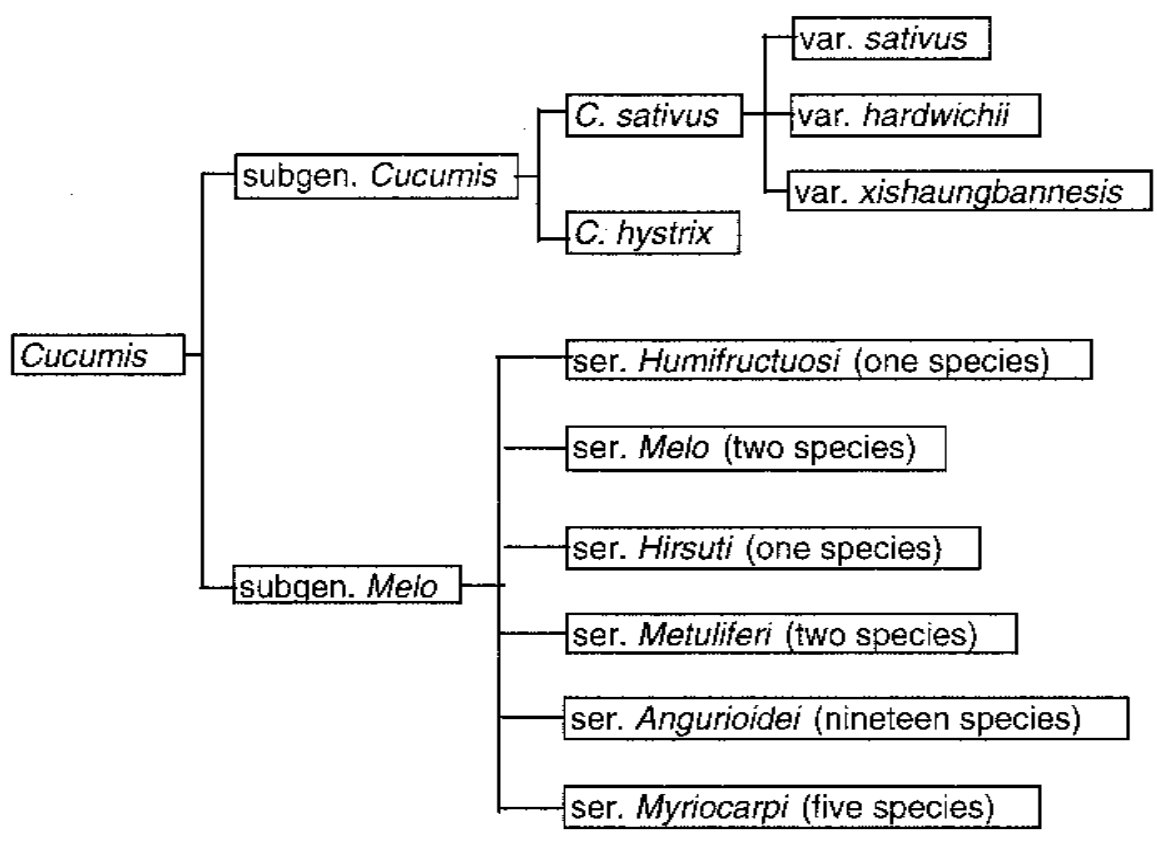

Fig. 3. The current Cucumis systematic system proposed by Kirkbride (1993).

Table 1. Grouping of Cucumis species by the studies on phylogenetic affinity.

\begin{tabular}{lccc}
\hline \hline Methods & No. groups & No. species used & \multicolumn{1}{c}{ Source } \\
\hline $\begin{array}{l}\text { Crossability } \\
\begin{array}{l}\text { Morphology and } \\
\text { chromosome pairing }\end{array}\end{array}$ & 4 & 14 & Deakin et al., 1971 \\
$\begin{array}{l}\text { Crossability, } \\
\text { chromosome pairing, }\end{array}$ & 5 & $13(2 \mathrm{n}=24)$ & Singh and Yadava, 1984a \\
$\quad \begin{array}{l}\text { and pollen fertility } \\
\text { ChlDNA variation }\end{array}$ & 6 & 8 & Singh and Yadava, 1984b \\
$\begin{array}{l}\text { Isozyme variability } \\
\text { Isozyme pattern }\end{array}$ & 6 & 21 & Perl-Treves and Galun, 1985 \\
\hline
\end{tabular}

African Cucumis have $\mathrm{n}=12$, and that Asian Cucumis have $\mathrm{n}=7$, which has governed the understanding of systematics and phylogenetics in Cucumis for decades. The taxonomic position of $C$. hystrix is of special interest because it bears a morphological resemblance and biochemical affinity to $C$. sativus while its chromosome number is the same as C. melo (Chen et al., 1995). Isozyme variability suggested a phylogenetic relationship between $C$. hystrix and both $C$. sativus and C. melo (Chen et al., 1997a). For instance, C. hystrix has four bands in the pattern of malate dehydrogenase (MDH) (Fig. 6). The first band is shared by all three species, indicating the common property of this genus. The second and third bands are identical with those in $C$. melo and C. sativus, respectively, indicating a connection to each species. The fourth band is a unique or specific band that distinguishes $C$. hystrix from both $C$. melo and $C$. sativus.

The first comprehensive crossability analysis of the genus was published by Deakin et al. (1971), who observed that crosses among wild species are frequently possible, but that all attempts to cross any of these with the two cultivated species, C. sativus and C. melo, failed. Other more successful interspecific hybridization studies between cultivated Cucumis crops and the wild relatives are presented in Table 2. However, in practice, most of these results were not repeatable and did not result in fertile hybrids. Our current understanding of the cross relationship based on the previous experiments is presented in Fig. 7. More work is needed for a precise placement of $C$. hystrix in the genus Cucumis and a better understanding of its specific relationship. Knowledge of species relationships are the key to success.

\section{MAJOR PROBLEMS IN INTERSPECIFIC HYBRIDIZATION AND THEIR SOLUTIONS}

\section{Hybridization barriers}

Many experiments have indicated the presence of a strong barrier to interspecific hybridization in Cucumis. The nature of cross-incompatibility between cultivated Cucumis species and their wild relatives is not well understood. Incompatibility is characterized by delayed growth of pollen, or arrested pollen tube growth in the stigma, or inability of pollen tubes to reach the ovules (Kishi and Fukishita, 1969), as well as lack of cell division of the zygote, and abortion of the endosperm (Kishi and Fukishita, 1970).

Several traditional approaches in interspecific hybridization have been used to overcome the hybridization barriers in Cucumis. 


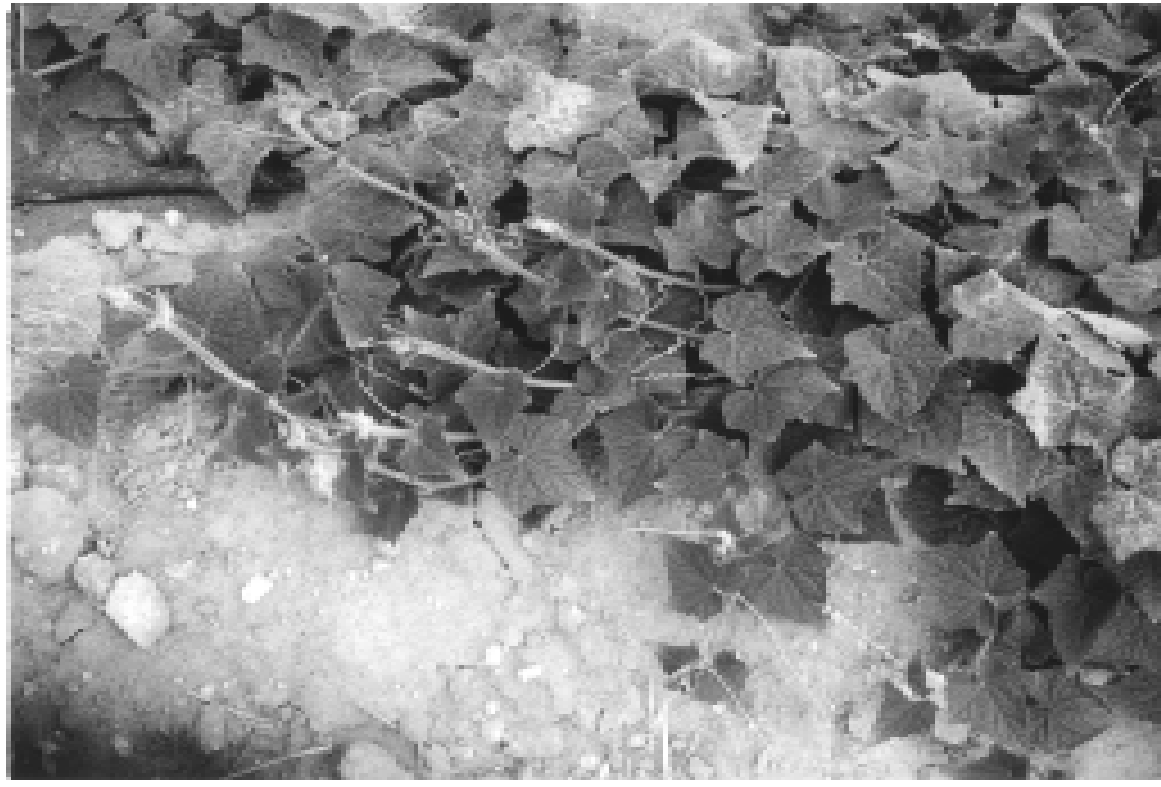

Fig. 4. Cucumis hystrix plant in the field.

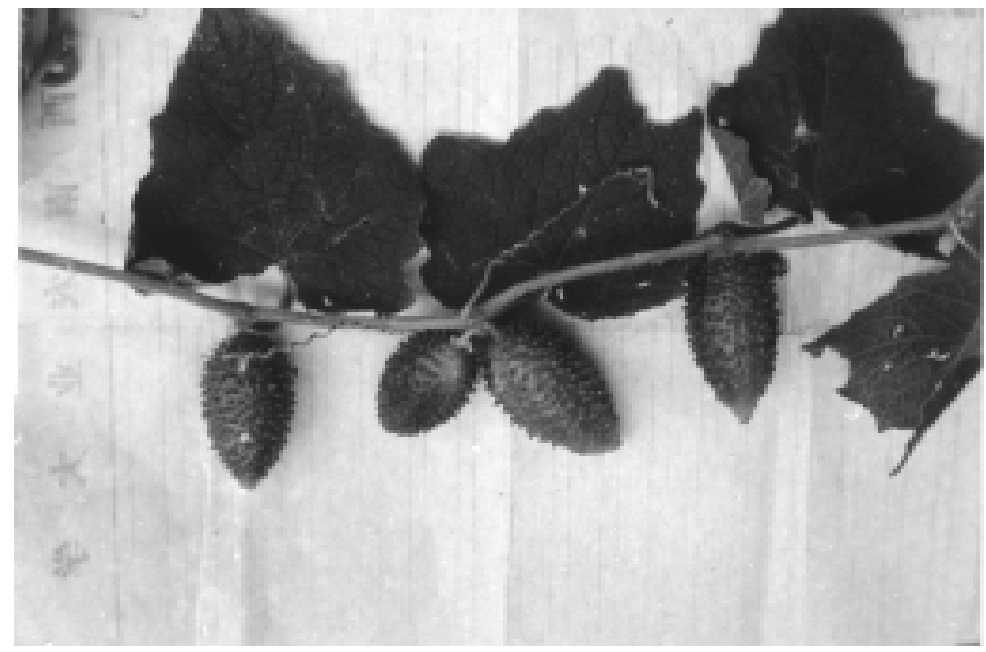

Fig. 5. Fruits on Cucumis hystrix plant.

These include growth regulator application (Custers and Den Nijs, 1986), pollen irradiation (Beharav and Cohen, 1994), use of mentor pollen (Kho et al., 1980), and bud pollination (Chatterjee and More, 1991). Biotechnological techniques such as somatic hybridization have also been suggested as possible tools for overcoming these barriers in Cucumis (Chartterjee and More, 1991; Tang and Punja, 1989). Likewise, fusion of $C$. sativus and $C$. melo protoplasts has been attempted, but the results indicated that successful hybridization is still unpredictable (Fellner et al., 1996).

The interspecific hybrid between $C$. sativus and C. hystrix (Chen and Staub, 1997) represents an important step in interspecific hybridization in Cucumis. If $C$. hystrix and $C$. melo are cross-compatible and if the $F_{1}$ derived from either interspecific hybridization can be made fertile through crossing and/or chromosome
C. prophetarum L. and C. melo (Singh and Yadava, 1984b). The authors believed that the barriers between these two species were postzygotic. If the embryo rescue technique had been employed, the experiment might have been successful. Interspecific hybrid embryos from reciprocal hybridizations in our studies were rescued successfully (Fig. 1A). Rescued embryos started growing within $3 \mathrm{~d}$, turned green in $5 \mathrm{~d}$, and rooted in $8 \mathrm{~d}$ on MS medium (Murashige and Skoog, 1962). About $40 \%$ of the embryos developed into whole plants (Chen et al., 1997b).

\section{Sterility in $F_{1}$ hybrids}

In our review of the literature on utilizing germplasm of wild species for crop improvement, a common problem was sterility in $F_{1}$ hybrids. In many cases, this sterility was associated with meiotic abnormalities, and was a large obstacle that followed hybridization and hindered utilization.

The ability to cross $C$. sativus and $C$. hystrix offered the promise of moving desirable characters from $C$. hystrix to $C$. sativus. However, self-pollination and backcrossing of the $F_{1}$ plants to either parent was unsuccessful because the original hybrid was both male- and female-sterile, probably because of the nonfunctional gametes containing odd chromosome numbers. When chromosomes were doubled, each chromosome had a homologous partner for pairing during meiosis; if there were no cytoplasmic incompatibility, the chromosome-doubled $\mathrm{F}_{1}$ hybrid might have produced viable gametes, and fertility restoration was anticipated.

External application of chemical agents is the usual way to double chromosome number. Among various agents, colchicine was one of the antimitotic substances most frequently used for this purpose (Chen and Staub, 1997). Colchicine in an aqueous solution of $\approx 0.05 \%$ to $0.5 \%(\mathrm{w} / \mathrm{v})$ is believed to be the most effective dosage for many plant species. Since colchicine is poisonous to plants, germinating seeds or young seedlings are often preferred for treatment because they grow rapidly and recover more readily than more mature plants do.

When the experimental material does not respond well to chemical treatment, in vitro chromosome doubling (spontaneous polyploidy as a consequence of tissue culture) could be an alternative (D'Amato, 1977). When and how the polyploidization happened in tissue culture was not entirely clear, but it occurred at a low rate during plant formation from axillary buds (Adelberg et al., 1994), callus (Osifo et al., 1989), and culture of protoplasts (Tabei et al., 1992). Polyploidization can be generalized as a universal phenomenon in melon tissue culture (Ezura et al., 1992), although genotype is an important factor in determining the rate of chromosome doubling (Adelberg and Chen, 1998). In our work with interspecific embryos, $\approx 7 \%$ of the regenerates were chromosome-doubled $F_{1}$ hybrids after organogenesis (Chen et al., 1998). More importantly, the polyploid regenerates obtained 


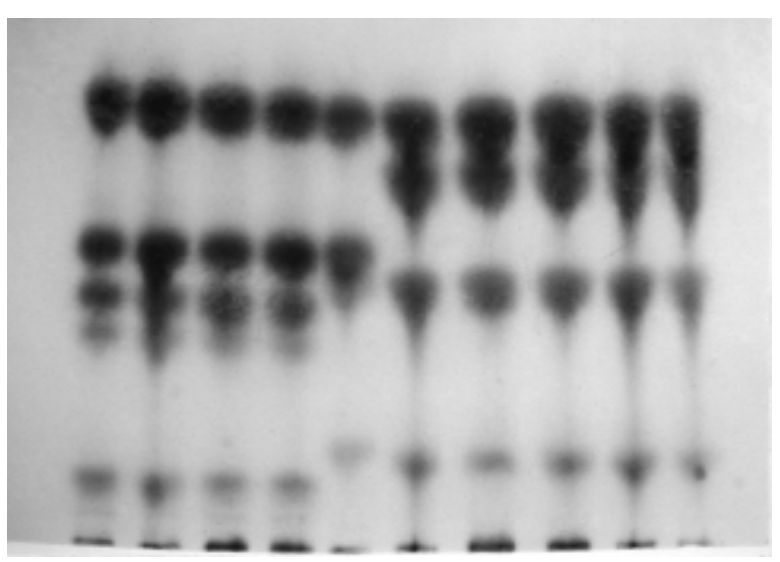

Fig. 6. Zymogram of malate dehydrogenase. Melon group (lines 1-4) has five bands, Cucumis hystrix (line 5) and cucumber group (line 6-10) have four bands. The first band in C. hystrix is the common band shared by all samples; the second is the same as in the melons while the third is the same as in cucumbers. The fourth band is a unique, and distinguishes $C$. hystrix from both melon and cucumber.

Table 2. Wide-cross attempts between cultivated and wild Cucumis species.

\begin{tabular}{|c|c|c|}
\hline Cross & Result & Source \\
\hline C. sagittatus $\times$ C. melo & Embryos only & Deakin et al., 1971 \\
\hline C. metuliferus $\times$ C. melo & Embryos only & Fassuliotis, 1977 \\
\hline C. sativus $\times$ C. melo & $\begin{array}{l}\text { Globular stage } \\
\text { embryos only }\end{array}$ & $\begin{array}{l}\text { Niemirowicz-Szczytt } \\
\text { and Kubicki, } 1979\end{array}$ \\
\hline C. metuliferus $\times$ C.melo & Fertile $F_{1}$ & Norton and Granberry, 1980 \\
\hline C. prophetarum $\times$ C. melo & $\begin{array}{l}\text { Fruit with inviable } \\
\text { seeds }\end{array}$ & Singh and Yadava, 1984b \\
\hline C. zeyheri $\mathrm{x}$ C. sativus & $\begin{array}{l}\text { Fruit with inviable } \\
\text { seeds }\end{array}$ & Custers and Den Nijs, 1986 \\
\hline C. sativus $\times$ C. metuliferus & Embryos only & Franken et al., 1988 \\
\hline C. melo $\times$ C. metuliferus & Embryos only & Soria et al., 1990 \\
\hline C. sativus $\times$ C. hystrix & $\begin{array}{l}\text { Sterile plants } \\
\quad(2 n \text { and } 4 n)\end{array}$ & Chen et al., 1997b \\
\hline C. hystrix $\times$ C. sativus & $\begin{array}{l}\text { Fertile plants } \\
\quad(4 n)\end{array}$ & Chen et al., 1998 \\
\hline
\end{tabular}

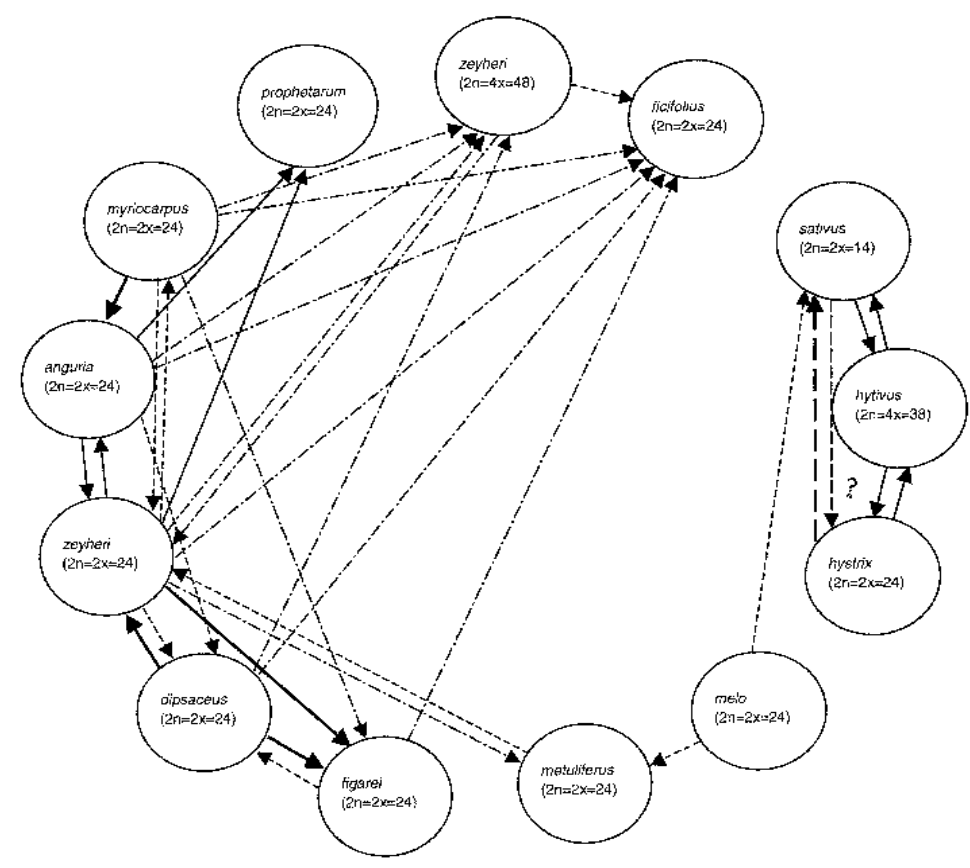

Fig. 7. Polygon of crossability in Cucumis species (modified from Nijs and Visser, 1985). Arrows point to the female parent. Moderately to strongly self-fertile and cross-fertile hybrids (thick solid line); sparingly self-fertile and moderately cross-fertile hybrids (thin solid line); self-fertile, usually not crossfertile hybrids (dashed and dotted line); inviable seeds or seedlings (dashed line); self-sterile and cross-sterile hybrids (thick dashed line); self-sterile and cross-fertile hybrids (long dashed line). Absence of a line indicates that seeded fruits were not obtained; question mark means that the information needs to be confirmed. through somaclonal variation were nonchimeral and vigorous.

\section{PERSPECTIVE: POTENTIAL OF UTILIZING OTHER WILD SPECIES}

An important long-term objective for Cucumis breeders is the introduction of genes from wild relatives. Some wild relatives, such as $C$. metuliferus E. Meyer ex Naudin (nematode resistance) and $C$. figarei Naudin (virus resistance), have long been attractive to scientists. However, progress through conventional crossing has been limited for lack of techniques and knowledge of species relationships. Cucumis hystrix is an important species for the investigation of phylogenetic relationships, especially between species with basic chromosome numbers of $n=7$ and $n=12$. New knowledge gained by investigation of these relationships might eventually enable us to successfully accomplish crosses between cultivated Cucumis and the other wild species.

\section{Literature Cited}

Adelberg, J.W. and J.F. Chen. 1998. Genetic control of regeneration was altered during one-week ripening of immature melon cotyledons on liquid/membrane system. Presented at IAPTCWorld Congress on Cell Culture, Jerusalem, Israel.

Adelberg, J.W. and B.B. Rhodes, H.T. Skorupska, and W.C. Bridges. 1994. Explant origin affects the frequency of tetraploid plants from tissue cultures of melon. HortScience 29:689-692.

Beharav, A. and Y. Cohen. 1994. Effect of gamma radiation on vitality and fertilization ability of Cucumis melo and C. metuliferus pollen. Cucurbit Genet. Coop. Rpt. 17:94-96.

Bowley, S.R. and N.L. Taylor. 1987. Introgressive hybridization, p. 23-59. In: B.R. Christie (ed.). CRC handbook of plant science in agriculture. vol. 1. CRC Press, Boca Raton, Fla.

Chatterjee, M. and T.A. More, 1991. Interspecific hybridization in Cucumis spp. Cucurbit Genet. Coop. Rpt. 14:69.

Chen, J.F., J.W. Adelberg, J.E. Staub, H.T. Skorupska, and B.B. Rhodes. 1998. A new synthetic amphidiploid in Cucumis from a C. sativus $x$ C. hystrix $\mathrm{F}_{1}$ interspecific hybrid, p. 336-339. In: J. McCreight (ed.). Cucurbitaceae '98Evaluation and enhancement of Cucurbit germplasm. ASHS Press, Alexandria, Va.

Chen, J.F., S. Isshiki, Y. Tashiro, and S. Miyazaki. 1995. Studies on a wild cucumber from China (Cucumis hystrix Chakr.). I. Genetic distances between $C$. hystrix and two cultivated Cucumis species (C. sativus $\mathrm{L}$. and C. melo L.) based on isozyme analysis. J. Jpn. Soc. Hort. Sci. 64(suppl. 2):264-265.

Chen, J.F., S. Isshiki, Y. Tashiro, and S. Miyazaki. 1997a. Biochemical affinities between C. hystrix and the two cultivated Cucumis species. Euphytica 97:139-141.

Chen, J.F. and J.E. Staub. 1997. Attempts at colchicine doubling of an interspecific hybrid of Cucumis sativus L. $\times$ C. hystrix Chakr. Cucurbit Genet. Coop. Rpt. 20:24-26.

Chen, J.F., J.E. Staub, Y. Tashiro, S. Isshiki, and S. Miyazaki. 1997b. Successful interspecific hybridization between Cucumis sativus $\mathrm{L}$. and $C$. hystrix Chakr. Euphytica 96:413-419.

Chen, J.F., S.L. Zhang, and X.G. Zhang. 1994. The xishuangbanna gourd (C. sativus var. xishuangbannesis Qi et Yuan), a traditionally 
cultivated plant of the Hanai people Xishuangbanna, Yunnan, China. Cucurbit Genet. Coop. Rpt. 17:18-20.

Custers, J.B.M. and A.P.M. Den Nijs. 1986. Effects of aminoethoxyvinylglycine (AVG), environment, and genotype in overcoming hybridization barriers between Cucumis species. Euphytica 35:639-647.

D'Amato, F. 1977. Cytogenetics of differentiation in tissue and cell cultures, p. 34-393. In: J. Reinert and Y.P.S. Bajaj (eds.). Plant cell, tissue and organ cultures. Springer-Verlag, Berlin.

Deakin, J.R., G.W. Bohn, and T.W. Whitaker. 1971. Interspecific hybridization in Cucumis. Econ. Bot. 25:195-211.

Den Nijs, A.P.M. and D.C. Visser. 1985. Relationships between African species of the genus Cucumis L. evaluated by the production, vigor and fertility of $F_{1}$ hybrids. Euphytica 34:279290.

Ezura, H., H. Amagai, K. Yoshioka, and K. Oosawa. 1992. Highly frequent appearance of tetraploidy in regenerated plants, a universal phenomenon in tissue culture of melon (Cucumis melo L.). Plant Sci. 85:209-213.

Fassuliotis, G. 1977. Self-fertilization of Cucumis metuliferus Naud. and its cross-compatibility with C. melo L. J. Amer. Soc. Hort. Sci. 102:336339.

Fellner, M., P. Binarova, and A. Lebeda. 1996. Isolation and fusion of Cucumis sativus and Cucumis melo protoplasts, p. 202-209. In: M.L. Gomez-Guillamon, C. Soria, J. Cuartero, J.A. Tores, and R. Fernandez-Munoz (ed.). Cucurbits towards 2000. Proc. 6th Eucarpia Mtg. on Cucurbit Genetics and Breeding, Malaga, Spain.

Franken, J., J.B.M. Custers, and R.J. Bino. 1988. Effects of temperature on pollen tube growth and fruit set in reciprocal crosses between Cucumis sativus and C. metuliferus. Plant Breeding 100:150-153.

Jeffrey, C. 1980. A review of the Cucurbitaceae. Bot. J. Linn. Soc. 81:233-247.

Kho, Y.O., A.M.P. den Nijs, and J. Franken. 1980. Interspecific hybridization in Cucumis L. II. The crossability of species, and investigation of in vitro pollen tube growth and seed set. Euphytica 29:661-672.

Kirkbride, J.H., Jr. 1993. Biosystematic monograph of the genus Cucumis (Cucurbitaceae). Parkway Publ., Boone, N.C.

Kishi, Y. and N. Fujishita. 1969. Studies on interspe- cific hybridization in the genus Cucumis. I. Pollen germination and pollen tube growth in selfings and incompatible crossings. J. Jpn. Soc. Hort. Sci. 38:329-334.

Kishi, Y. and N. Fujishita. 1970. Studies on interspecific hybridization in the genus Cucumis. II. Pollen tube growth, fertilization and embryogenesis of post-fertilization stage in incompatible crossing. J. Jpn. Soc. Hort. Sci. 39:51-57.

Laibach, F. 1925. Das Taubwerden von Bastardsamen und die kunstliche Aufzucht fruh absterbender Bastardembryonen. Z. Bot. 17:417459.

Leppick, E.E. 1966. Searching gene centers of the genus Cucumis. Euphytica 15:323-328.

Lower, R.L. and M.D. Edwards. 1986. Cucumber breeding, p. 173-207. In: M.J. Basset (ed.). Breeding vegetable crops. AVI, Westport, Conn.

Murashige, T. and F.A. Skoog. 1962. A revised medium for rapid growth and bioassays with tobacco tissue cultures. Physiol. Plant 15:473497.

Naudin, C. 1859. Revue des Cucurbitaceae cultivees au museum en 1859. Ann. Sci. Nat. Ser. 4 Bot. 12:79-164.

Niemirowicz-Szczytt, K. and B. Kubicki. 1979. Cross fertilization between cultivated species of genera Cucumis L. and Cucurbita L. Genetica Polonica 20:117-125.

Norton, J.D. and D.M. Granberry. 1980. Characteristics of progeny from an interspecific cross of Cucumis melo with C. metuliferus. J. Amer. Soc. Hort. Sci. 105:174-180.

Osifo, E., J.K. Webb, and G.G. Henshaw. 1989. Variation amongst callus derived potato plants Solanum brevidens. J. Plant Physiol. 134:1-4.

Perl-Treves, R. and E. Galun. 1985. The Cucumis plastome: Physical map, intrageneric variation and phylogenetic relationships. Theor. Appl. Genet. 71:417-429.

Perl-Treves, R., D. Zamir, N. Navot, and E. Galun. 1985. Phylogeny of Cucumis based on isozyme variability and its comparison with plastome phylogeny. Theor. Appl. Genet. 71:430-436.

Puchalski, J.T. and R.W. Robinson. 1990. Electrophoretic analysis of isozymes in Cucurbita and Cucumis and its application for phylogenetic studies, p. 60-76. In: D.M. Bates, R.W. Robinson, and C. Jeffrey (eds.). Biology and utilization of the Cucurbitaceae. Cornell Univ. Press, Ithaca, N.Y.

Robinson, R.W. and D.S. Decker-Walters. 1997.
Interspecific hybridization, p. 51-55. In: R.W. Robinson and D.S. Decker-Walters (eds.). Cucurbits. CAB Intl., Oxon, U.K.

Singh, B.P. 1991. Interspecific hybridization in between new and old-world species of Luffa and its phylogenetic implication. Cytologia 56:359365.

Singh, A.K. and K.S. Yadava. 1984a. Cytogenetics of Cucumis L. IV. Comparative study of natural and induced polyploids. Cytologia 49:183-192.

Singh, A.K. and K.S. Yadava. 1984b. An analysis of interspecific hybrids and phylogenetic implications in Cucumis (Cucurbitaceae). Plant Syst. Evol. 147:237-252.

Soria, C., M.L. Gomez-Guillamon, J. Esteva, and F. Nuez. 1990. Ten interspecific crosses in the genus Cucumis: A preparatory study to seek crosses resistant to melon yellowing disease. Cucurbit Genet. Coop. Rpt. 13:31-33.

Stalker, H.T. 1980: Utilization of wild species for crop improvement. Adv. Agron. 33:111-147.

Staub, J.E., L. Fredrich, and T.L. Marty. 1987. Electrophoretic variation in cross compatible wild diploid species of Cucumis. Can. J. Bot. 65:792-798.

Stebbins, G.L. 1971. Chromosomal evolution in higher plants. Addison-Wesley, London. p. 216.

Tabei, Y., T. Nishio, and T. Kanno. 1992. Shoot regeneration from cotyledonary protoplasts of melon (Cucumis melo L. cv. Charentais). J. Jpn. Soc. Hort. Sci. 61:317-322.

Tang, F.A. and Z.K. Punja. 1989. Isolation and culture of protoplasts of Cucumis sativus and Cucumis metuliferus and methods for their fusion. Cucurbit Genet. Coop. Rpt. 12:29-32.

Valvilov, N. 1925. Inter-genetic hybrids of melons, watermelons and squashes. Bul. Appl. Bot. Genet. Plant Breeding 14:3-35.

Weeden, N.F. and R.W. Robinson. 1986. Allozyme segregation ratios in the interspecific cross Cucurbita maxima $\times$ C. ecuadorensis suggest that hybrid breakdown is not caused by minor alterations in chromosome structure. Genetics 114:593-609.

Yadava, K.S., A.K. Singh, R.P. Roy, and U.C. Jha. 1986. Cytogenetics in Cucumis L. VI. Synthetic amphidiploids. Nucleus 29:58-62.

Zillinsky, F.J. 1985. Triticale: An update on yield, adaptation, and world production, p. 1-7. In: R.A. Forsberg (ed.). Triticale. Crop Sci. Soc. Amer. Spec. Publ. No. 9. Amer. Soc. Agron., Madison, Wis. 